\title{
26. FACIES AND PALEOENVIRONMENT OF LOWER CRETACEOUS SEDIMENTS AT DSDP SITE 397 AND IN THE AAIUN BASIN (NORTHWEST AFRICA)
}

\author{
Gerhard Einsele, Institut für Geologie und Paläontologie der Universität Tübingen, D 7400 Tübingen, \\ Federal Republic of Germany \\ and \\ Ulrich von Rad, Bundesanstalt für Geowissenschaften und Rohstoffe (Federal Geological Survey), D 3000 \\ Hanover, F. R. Germany
}

\begin{abstract}
At the uppermost continental rise off Cape Bojador, 153 meters of upper Hauterivian, laminated, gray, silty claystones were penetrated below a 1300-meter-thick Neogene section. These claystones are rich in terrigenous components (quartz, mica, plant debris), fish remains, and organic carbon, but poor in carbonate and microfossils. The sequence contains many thin layers and some nodules of siderite which was precipitated during early diagenesis after the formation of pyrite and may have replaced earlier calcite. Locally, a few thin layers of well-sorted silt to fine sand occur, and also marls with a well-preserved nannoflora.

Within a three-dimensional facies model for the Early Cretaceous continental margin, the upper Hauterivian sediments of Site 397 are interpreted as being distal prodelta muds, rapidly deposited ( 75 to $150 \mathrm{~m} / \mathrm{m} . \mathrm{y}$.) in an oxygen-depleted environment and in a water depth of a few hundred to thousand meters. They are comparable to deposits from recent (e.g., Niger) and Early Cretaceous (e.g., Nova Scotian shelf) deltaic environments. Coeval sediments from a nearby commercial shelf well and from outcrops in the Aaiun-Tarfaya coastal basin represent the landward (neritic, intertidal-lagoonal, alluvial plain) subenvironments of a widespread delta system. The source area of the rapidly deposited deltaic sediments were uplifted Precambrian and Paleozoic rocks of the Requibat Massif, Mauritanides, and/or Anti-Atlas Mountains. Heavy minerals suggest a plutonic source area; plant fragments and clay mineral associations indicate weathering under a temperate, humid climate.

After the "Wealden-type" phase of a prograding delta, the Middle Cretaceous transgression initiated a landward facies migration. This lead to a fining-upward "megacycle" and a decrease of the terrigenous and a relative increase of the biogenic input. An expanded oxygen-minimum zone and/or regional upwelling during the late Cenomanian/Turonian generated laminated bituminous marls in the coastal basin. The present coastline is situated between the Early and mid-Cretaceous strandlines. The present outer shelf edge was not formed before about the Cenomanian/Turonian.
\end{abstract}

\section{INTRODUCTION}

One of the objectives of Leg 47A was to study the Early Cretaceous paleoenvironment and sedimentary history of the Cape Bojador continental margin. However, not before a 1300-meter-thick Neogene section had been penetrated, did the core barrel first reveal an enigmatic Lower Cretaceous sequence of medium gray, partly laminated, and almost barren mudstones with thin yellowish brown "dolomite" intercalations. Because of time constraints and extremely low penetration rates, only 153 meters of the more or less homogeneous formation were penetrated. This was insufficient to reach the base of the Cretaceous which, due to the apparently increasing accumulation rates, may occur at considerably greater depth.

Although the recovered sediments may represent less than 2 per cent of Cretaceous time, they revealed a remarkable facies forming the hitherto unknown seaward equivalent of the well-surveyed Aaiun Basin sequence (AUXINI, 1969; Ratschiller, 1970). The strange facies of the Lower Cretaceous strata of Site 397 raises a number of important questions concerning sedimentation and paleoenvironment of these deposits. We will try to tentatively answer some of these questions in the context of the Early Cretaceous evolution 
of the Cape Bojador continental margin (1) by studying the fabric, texture, and composition of the sediments; and (2) by correlating these results with the Lower to Middle Cretaceous facies of nearby DSDP Sites 369 and 416 , on- and offshore commercial wells, and outcrops of the Aaiun coastal basin.

\section{LITHO- AND BIOFACIES OF LOWER CRETACEOUS UNIT 5 IN DSDP SITE 397}

\section{Lithology and Sedimentary Structures}

The age, generalized lithology, fabric, texture, and composition of the Lower Cretaceous "lithostratigraphic unit 5" (see Lithostratigraphy section of the Site Report, this volume) are shown in Figure 1. The major lithology is a medium gray (N 6) homogeneous or finely laminated quartzose silty claystone ("mudstone") with regular intercalations of yellowish gray $(5 \mathrm{Y} 7 / 2)$ siderite layers. In Cores 397A-37, 39, 47, and 48, a few thin (1 to $20 \mathrm{~mm}$ ) layers of well-sorted siltstone to very fine sandstone (max. $130 \mu \mathrm{m}$ ) occur. They are usually not graded (Figure 2B); Plate 1, Figure 1). Only a few thin siltstone laminae show an upward decrease of the quantity (and size) of quartz grains and an increase of clay (and siderite) content (Plate 2, Figure 3; Figure 2C). Pyrite and heavy minerals are concentrated near the base of the (graded) sand layer.

The most conspicuous fabric type of this sequence is a distinct "varve-like," mm-rhythmic, parallel lamination (Plate 1, Figure 7), produced by fluctuations of textural (silt content) and/or compositional parameters. Usually, the darkcolored (medium light-gray) laminae ( $\mathrm{a}$ in Figure $3 \mathrm{~A}$ ) consist of silty clay that is rich in quartz, mica, pyrite, phosphatic fish debris, and plant fragments. The light gray laminae ( $b$ in Figure 3A) are virtually quartz-free "pure" claystones, often only 0.1 to $0.3 \mathrm{~mm}$ thick. Dark brown, streaky claystone lenses rich in organic material (?) represent a third bedding type (c in Figure 2A; Plate 2, Figure 1) which is probably produced by burrowing organisms. The lamination is stressed by the orientation of mica flakes and plant fragments parallel to bedding planes (Figure 2B). Thin-sections and SEM photomicrographs reveal that the individual laminae are very different in thickness and often are not strictly parallel (as "varves" or seasonal rhythmites deposited in glacial lakes or lagoons), but lenticular in shape ("flaser bedding,"' see Plate 1, Figure 2; Plate 2, Figure 1).

The bedded character of the sequence is also revealed by frequent well-indurated siderite intercalations (see below).

Small-scale cross-lamination is very rare (Plate 1, Figure 7), as are small erosional disconformities or cutand-fill structures (Plate 1, Figures 2 and 5). Slumping (Cores 397A-47 and 50 through 52), on a small scale, is indicated by contorted crinkled lamination, recumbent convolute folds (Plate 2, Figure 4; Figure 3B) as well as folded, downfaulted, and pulled apart ("boudinage-structure") siderite layers (Figure 3A; Plate 2, Figure 2). Lensy and streaked-out siderite layers (Plate
3, Figure 1) suggest early diagenetic shearing of semiindurated sediments parallel to bedding. These structures were probably caused by slow creep or slumping down an unstable slope, although the apparent dip angles measured in our cores ( 10 to $30^{\circ}$ ) might be partly due to core disturbance and an unknown degree of hole inclination.

Distinct bioturbation is absent in most cores (see Figure 1). Exceptions are (1) indistinct mottling, (2) distinct burrows of dark material, mostly parallel to the bedding plane (Figure 2A, Plate 2, Figure 1), and (3) very small Helminthoid-type burrows (Cores 397A-46 and 50 ).

In general, the compaction (induration) and sediment density increases from the top to the base of the section (Figure 1).

\section{Composition and Texture}

\section{Claystones, Silty Claystones, and Siltstone Layers}

"Pure" claystones containing only a few per cent of quartz-size silt are rare. They consist of clay minerals showing aggregate polarization (extinction of large aggregates parallel to bedding under crossed nicols; Figure $2 \mathrm{~A}$ ). The SEM shows aggregates of phyllosilicates with intergrowth of authigenic carbonates. Detrital carbonate (calcite or dolomite?) and biogenous calcite (coccoliths, benthic foraminifers, mollusks, ostracodes) are very rare. LECO-carbonate determinations generally indicate less than 5 per cent inorganic carbon calculated as $\mathrm{CaCO}_{3}$ (coccoliths?), whereas X-ray diffraction analyses did not detect any calcite or siderite.

Silty claystone ("mudstones") containing 10 to 40 per cent quartz silt and less than 10 per cent " $\mathrm{CaCO}_{3}$ " is the most abundant sediment type. The quartz silt often is concentrated in lenses and laminae. Usually, the mudstones are poorly sorted with 50 to 90 per cent clay minerals $(<2 \mu \mathrm{m})$; the quartz silt ranges in size from 10 to $120 \mu \mathrm{m}$ with a strong maximum between 20 and $50 \mu \mathrm{m}$. The quartz grains are angular (only the larger ones are partly subrounded), clear, and rarely frosted or stained. The quartz grains are irregularly dispersed in the clay matrix (mud-support). Mica (mostly muscovite) and chlorite ( 1 to $5 \%$ ), feldspar (traces to $5 \%$ ), and pyrite (framboidal or micronodular, 1 to $10 \%$ ) are common constituents. Common heavy minerals include apatite, tourmaline, zircon, and amphibole, indicating an igneous (plutonic) source area (Figure 1). Dark-brown to black, land-derived plant fragments (up to $2 \mathrm{~mm}$ ) and carbonized wood fragments are very common (3 to $10 \%$ ), especially in dark colored laminae. Up to 90 per cent of the organic material consists of land-derived wood and plant fragments (Cornford, this volume; Basov et al., this volume). Spheroidal aggregates with a diameter of 30 to $50 \mu \mathrm{m}$ (probably megaspores) may comprise up to 10 per cent of the total sediment volume (Plate 1, Figure 6). Organic carbon ranges from 0.4 to 0.8 per cent.

Carbonate contents are small $(<5 \%$ according to shipboard and DSDP $\mathrm{CO}_{2}$ determinations) and could not be verified as either calcite or siderite by X-ray 
diffraction analyses. According to thin sections, the carbonate should be calcite (traces of coccoliths, a few foraminifers, shell fragments, etc.). Echinoderm skeletal parts (Cores 397A-46 through 48), echinoid spines, and otoliths are reported by Lutze (Site Report, this volume).

Clayey to very fine sandy quartz siltstone layers alternating with silty claystone are rare (Figure 2B). In one silt layer of Core 397A-39 (Plate 1, Figure 1; Figure $2 \mathrm{C}$ ), the quartz silt is moderately to well-sorted, densely packed ("grain support"), and cemented by 40 to 50 per cent macrocrystalline sparry calcite (individual crystals sometimes 1 to $3 \mathrm{~mm}$ ). Pyrite formation must have preceded calcite cementation.

\section{Nannofossil Marlstones}

Only exceptionally (e.g., in Cores 397A-42, 46, and 47; Plate 1, Figure 7), do the mudstones contain more than 10 per cent $\mathrm{CaCO}_{3}$ (calcareous mudstones) or up to 45 per cent $\mathrm{CaCO}_{3}$ (nannofossil marlstones), mostly as well-preserved coccoliths (see Figure 1; Čepek, and Wind, this volume). These are also the intervals where comparatively "rich" foraminiferal assemblages and a few ammonite and mollusk fragments (Wiedmann, this volume) were found.

\section{Sideritic Mudstone and Micrite (Layers and Nodules)}

Intercalations of yellowish gray ( 5 Y $7 / 2)$ to brown well-indurated siderite layers (identified aboard ship as "dolomite") are very common (see Figure 1; Plate 1, Figure 8). Trace amounts of $\mathrm{Fe}$-dolomite are also present (Basov et al., this volume). In some cores, these thin $(0.5$ to $10 \mathrm{~mm})$ layers occur at regular intervals with a spacing of 10 to $30 \mathrm{~cm}$. Usually the size of the individual carbonate rhombs is extremely small $(<1$ to $2 \mu \mathrm{m}$ : see Plate 2, Figures 5 and 6 ). Some layers contain only 20 to 50 per cent siderite ("sideritic mudstones"), but usually they consist of $>80$ per cent micritic siderite, apparently of early diagenetic origin. However, finely dispersed quartz silt ( 5 to $7 \%$ ), plant fragments (3\%), some calcite (inner part?), and small proportions of clay minerals (?) are always present. Small siderite concretions or nodules, 0.5 to $3.0 \mathrm{~cm}$ in diameter, occur especially in Cores $397 \mathrm{~A}-50$ to 52 (Plate 2, Figure 4; Plate 3, Figure 2). Concentric sideritic layers around one nodule suggest that it formed in the center of an overturned slump fold (Plate 3, Figure 1; Figure 3B). Another nodule (Sample 397A-51-3, $57 \mathrm{~cm}$ ) has a pyritic core, proving that the pyrite was precipitated prior to the siderite (see also Figure $3 \mathrm{~B}$ ).

\section{BIOSTRATIGRAPHY}

The foraminiferal fauna of lithostratigraphic Unit 5 is extremely sparse, dwarfed, and (in part) poorly preserved and pyritized. Also, several horizons contaminated with Neogene species were noted (Dr. G. Lutze, Dr. A. Butt, personal communication).

The study of 150 samples from Cores 52-34 by Dr. A. Butt (Tübingen) has shown that the foraminifers are mainly represented by miliolids, nodosariids, epistominas, and a few agglutinated specimens. Although the planktonic foraminifers are rare, they are well preserved including species like Hedbergella sp. aff. Hed. hoterivica, Hedbergella sigali, and Globigerinelloides blowi. These planktonic species including some other benthic species of the genus Epistomina indicate upper Hauterivian-Barremian to Barremian-Aptian age of the Cretaceous part of the sedimentary section at Hole 397A.

The determination of the ammonite Protetragonites cf. $P$. crebrisulcatus (Uhlig) in Sample 397A-39-2, CC by Wiedmann (this volume) indicates a Barremian age and does not contradict the foraminiferal results, whereas one specimen of Neocomites gr. N. neocomiensis (d'Orbigny, = Valanginian/Hauterivian) in Core 397A47 supports a late Hauterivian age.

According to nannoplankton determinations Čepek and Wind, this volume) however, Samples 397A-34-1, $109 \mathrm{~cm}$ to 397A-52-2, CC belong to the lower part of the late Hauterivian Lithraphidites bollii to Calcicalathina oblongata to Cruciellipsis cuvieri Zone). The presence of Cruciellipsis cuvillieri Čepek and Wind, this volume), with an extinction level within the late Hauterivian, might indicate the minimum age.

\section{EARLY CRETACEOUS PALEOENVIRONMENT OF THE CONTINENTAL MARGIN (AAIUN BASIN TO SITE 397)}

\section{Depositional Setting and Paleodepth}

The dominance of the clay fraction, mica, and plant debris; the presence of fine laminations; and the excellent preservation of fragile aragonitic tests of ammonites (Wiedmann, this volume), Epistominas, and thinshelled pelecypods (Legumen sp., Wiedmann, this volume) and gastropods suggest a low-energy environment below wavebase and above the aragonite compensation depth (see Lithostratigraphy, Biostratigraphy, Paleoenvironment, Site Chapter, this volume). The preservation of aragonistic shells is also favored by the presence of organic matter. Since photosynthetic organisms (algae) are missing, a water depth greater than 100 meters must be postulated. On the basis of foraminiferal paleoecology, an outer shelf to upper slope environment might be inferred (Dr. A. Butt, personal communication). We envisage a water depth of a few Hauterivian to early Barremian sediments of DSDP Site 397 as prodelta deposits ( $\mathrm{G}$ in Figure 4). This assumption is supported by paleogeographic-paleotectonic considerations (fig. 6; von Rad and Einsele, in press) and by the observation of (?) penecontemporaneous slump structures (Figure 3A). Some further evidence supporting this inference is described below.

\section{Lithofacies and Mode of Sedimentation}

Texture and sedimentary structures of the Early Cretaceous at Site 397 (Figures 1 and 2; Plates 1 and 2) agree fairly well with modern prodelta sediments.

The Niger delta (Allen, 1965; Oomkens, 1974) may be used as a recent equivalent because of its location off western Africa, large sediment input, and somewhat similar climatic conditions in the hinterland. Bedded 


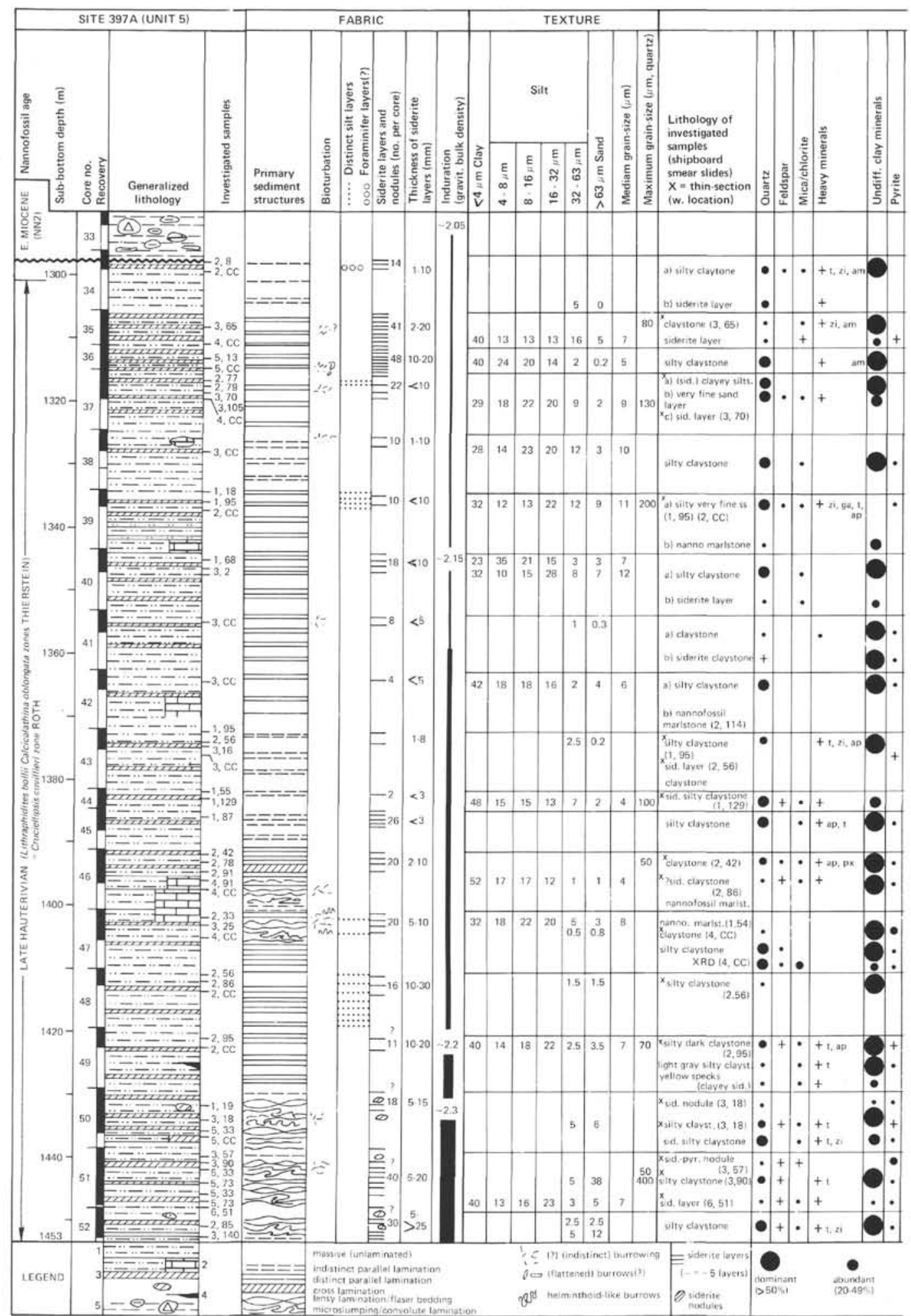

Figure 1. Age, lithology, fabric, texture, mineralogical composition, microfauna/nannoflora, and chemistry of Lower Cretaceous lithostratigraphic Unit 5. Coccoliths: after Čepek and Wind (this volume); foraminifers after A. Butt (personal communication): "Hedbergella spp." includes H. hauterivica and H. infracretacea; "arenaceous foramin." includes Rhizammina, Ammodiscus, Dorothia; "Nodosariidae" include Dentalina, Lenticulina, Astaculus. Other fossils after Lutze (Site Report, this volume). Abbreviations: lithology: $1=$ silty claystone to clayey siltstone (mudstone), 2 = nannofossil marlstone, $3=$ siderite layers or nodules, 4 = charcoal (plant debirs), $5=$ pebbly mudstone with porcellanite fragments. Sediments: $\mathrm{cl}=$ clayey, clayst(one), marlst(one), siltst(one), ss $=$ sandstone, $l t=$ light, yel $=$ yellowish. Minerals: $a m=$ amphibole, ap $=$ apatite, $p x=$ pyroxene, sid $=$ siderite,$t=$ tourmaline, $z=$ zircon. 


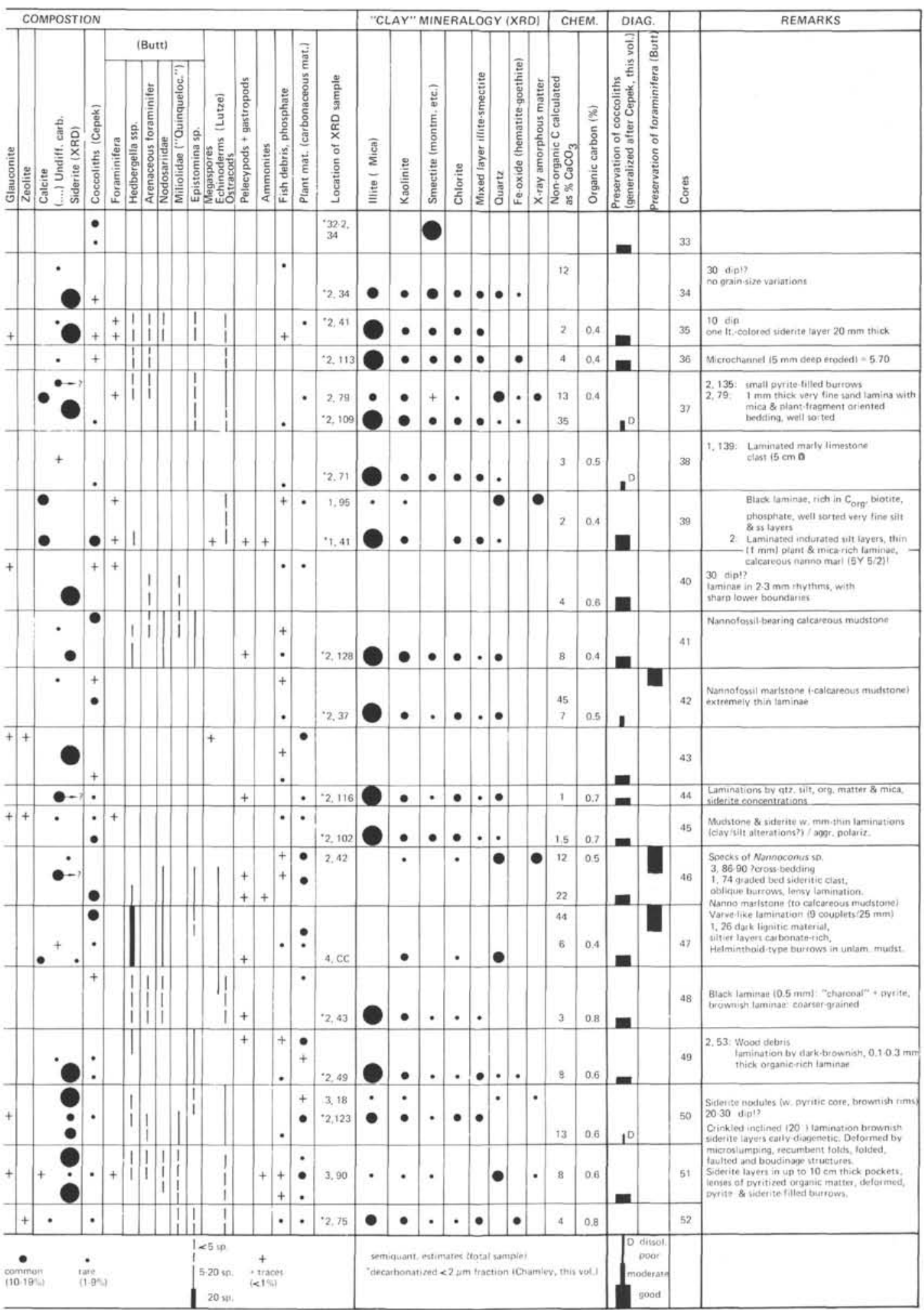

Figure 1. (Continued).

and laminated deposits of silty clays and clayey silts with plant debris and mica are encountered on the prodelta slope and open shelf of this delta. In the axial region of the delta, the coarse bands of silt or very fine sand are rarely thicker than $5 \mathrm{~cm}$. Most of the bands are thinner than $1 \mathrm{~cm}$, "many being irregular wisps or laminae a few grains thick" (Allen, 1965, p. 585), whereas the silty clay layers typically reach thicknesses of 20 to $30 \mathrm{~cm}$. Beyond the axial zone of the prodelta, the green to gray clayey silts and silty clays are in- 


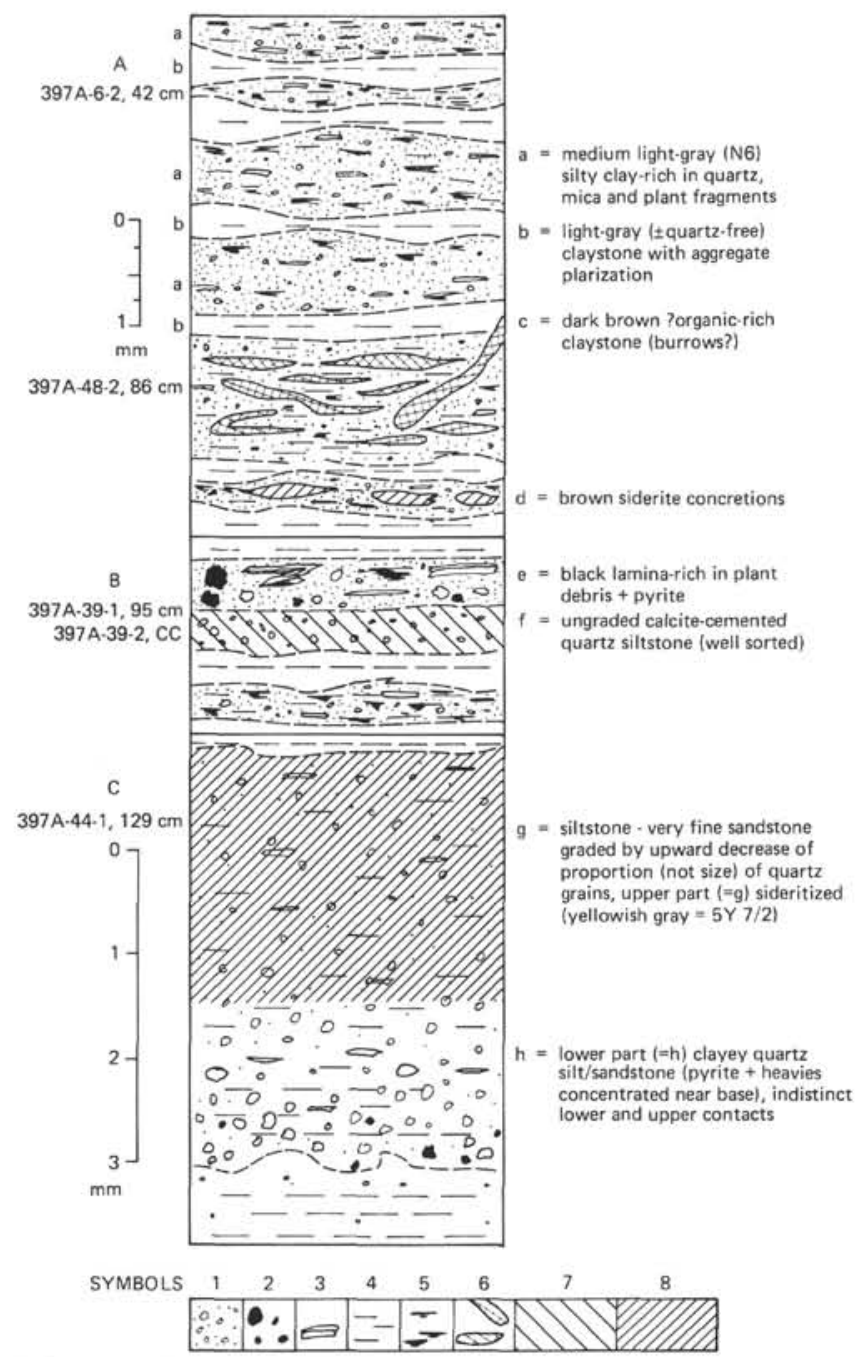

Figure 2. Generalized sketches of typical sedimentary structures drawn after core and thin-section photos. Symbols: 1 = (quartz) silt (to very fine sand), 2 = pyrite $(+$ heavy minerals $), 3=$ mica-chlorite, $4=$ clay minerals, $5=$ carbonaceous matter (plant debris, etc.), $6=$ ?organic-rich dark-colored clay, $7=$ calcitic cement (microspar-micrite), $8=$ siderite.

tensely burrowed. The layered axial prodelta facies extend from the delta platform to about 40 meters water depth (with maximum slopes of $0.25 \%$ ); the clayey bioturbated open shelf facies extend to a water depth of 100 to 200 meters. Further offshore and downslope, silts and sands are found intercalated in hemipelagic oozes at the foot of the present continental slope, where they were transported by turbidity currents (Burke, 1972).

Similarly, Mississippi and Guadalupe prodelta clayey silts and silty clays extend from about 200 meters down to almost 200 meters water depth (Gould, 1970; Reineck and Singh, 1973). The average grain-size distribution of the silty clays is 68 per cent clay, 30 per cent silt, and 2 per cent sand. The Mississippi prodelta consists of thinly parallel and lenticular laminated silts and clays rich in wood fragments. "Prodelta deposits are distinguished from bay deposits by darker color, well-developed lamination, fewer fossils and less bioturbation" (Donaldson et al., 1970).

Since graded sand layers are almost completely missing, the clay and silt-sized material were probably transported and deposited by "turbid layers" (Moore, 1968), very low-density "clouds" of clay and silt suspensions stirred up from the shelf or the delta front by waves, bottom or tidal currents, and moving slowly downslope following the pull of gravity (von Stackelberg, 1972). This produced poorly sorted silty clays with irregularly dispersed, mud-supported quartz grains. Redeposition by nepheloid layers (contour currents) can not be excluded. Only rarely did turbidity currents reach the prodelta, possibly by overflow from channels onto the open prodelta "fan." There they deposited very thin, well-sorted silt to very fine sand layers.

\section{Biofacies and Sedimentation Rate}

The scarcity of benthic as well as most of the planktonic organisms, the low carbonate content, the nearly complete absence of bioturbation and, therefore, the preservation of fine lamination suggest oxygen depletion and a relatively rapid sedimentation rate of landderived material typical of a prodelta environment. This is compatible with the abundance of plant debris (indicating certain climatic conditions in the hinterland) and to frequent fish remains (which show that fish were attracted by such an environment).

Biostratigraphic evidence supports the inference that the paucity of many biogenic constituents is mainly due to dilution by rapidly deposited terrigenous material. According to Čepek and Wind (this volume), the 150meter-thick sequence between Cores 397A-34 and 397A-52 belongs in the Lithraphidites bollii to Calcicalathina oblongata zones (i.e., lower portion of the late Hauterivian). The cored interval represents 1 (to 2) m.y. after the van Hinte (1976) time scale, resulting in an accumulation rate of (75 to) $150 \mathrm{~m} / \mathrm{m}$.y. or $(0.08$ to) $0.15 \mathrm{~mm} /$ year. Since many of the fine laminations are of the same order of magnitude $(0.1$ to $0.5 \mathrm{~mm}$; Plate 1, Figures 2 and 7), it may even be possible that part of the individual laminae are rhythmites produced by annual (seasonal) climatic variations. Alternately, longer period climatic fluctuations or recurring or episodic events like strong storms might have controlled the input of clay versus quartz silt, organic matter, and mica.

Occasional changes from rapid to decreasing rates of terrigenous sedimentation or restricted environmental conditions may have caused the variations in the content and preservation of biogenic $\mathrm{CaCO}_{3}$. Only in some cores (see Figure 1), are benthic and planktonic foraminifers, echinoid fragments, otoliths, and mollusks comparatively abundant and well preserved. In Cores 42, 46, and 47 of Hole 397A, the nannoflora is very well preserved (no overgrowth) and have high abun- 

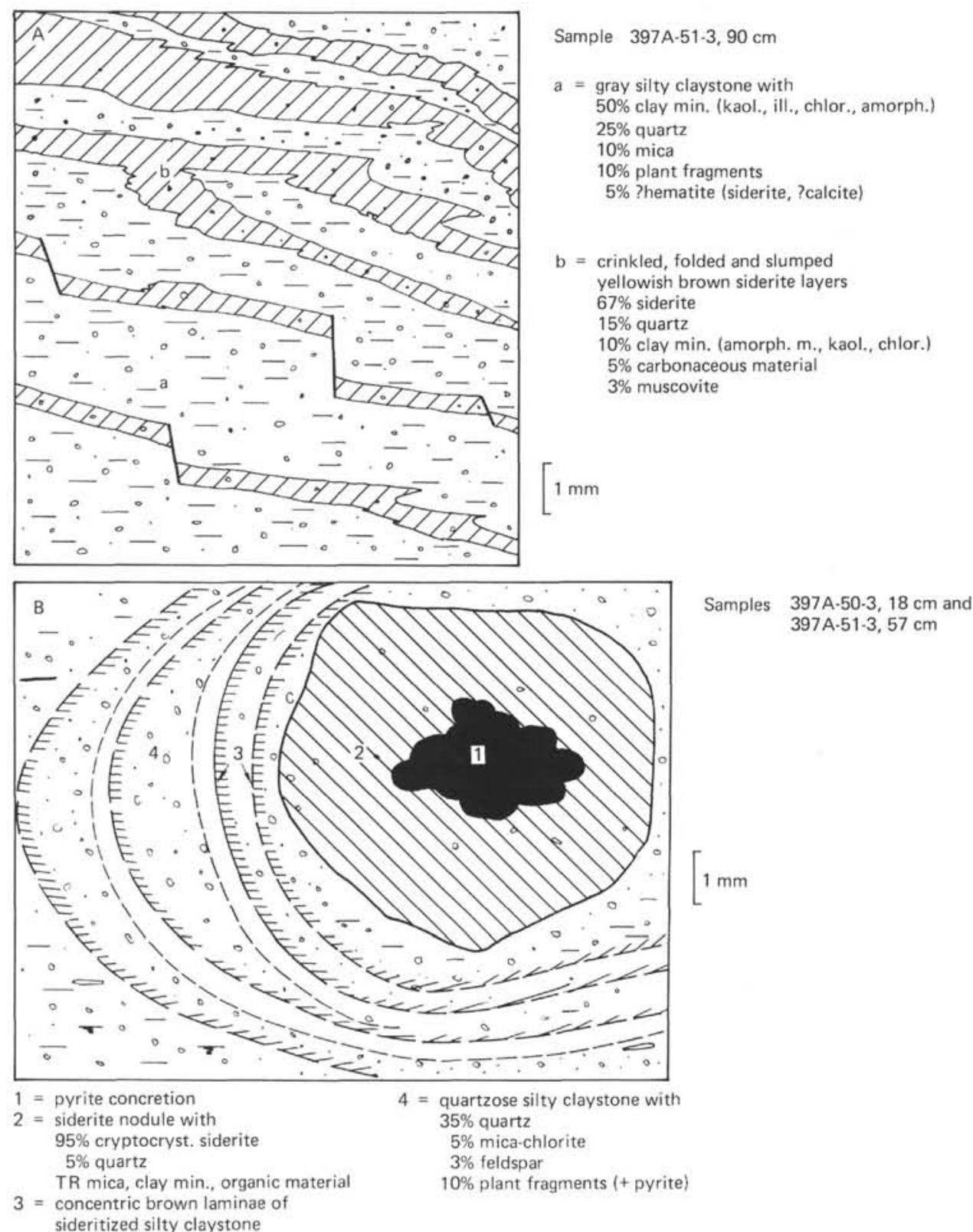

Figure 3. Siderite in layers (Figure $3 A$ ) or nodules (Figure 3B). Crinkling, "folding," and "faulting" of siderite (or their precursor calcite) layers may have occurred contemporaneously or after early diagenesis by slumping on a paleoslope. Note pyritic core (from decayed organic material?) in the nodule center (Figure $3 B$ ) which must have predated the formation of the siderite concretion or its calcitic precursor.

dance and diversity. In fact, those cores contain the most complete and best-preserved Hauterivian nannoflora, thus far obtained from DSDP sites (F. H. Wind, personal communication). Nevertheless, some biogenic carbonate certainly was dissolved within the sediment, based on abundant corroded coccoliths composed of stable low-Mg calcite. This carbonate was reprecipitated as sparry cement in porous sand and silt layers (see Plate 1, Figure 1; Figure 2C).

\section{Oxygen Depletion}

Not all characteristics of the litho- and biofacies can be explained by rapid sedimentation and dilution of the biogenic constituents. In combination with low-energy conditions below wave base, oxygen depletion and even local poisoning of the bottom water may have occured. This is suggested by the dwarfed nature of some foraminiferal associations, by the preservation 
of high amounts of organic matter (up to $1 \%$ organic carbon), and by the abundance of pyrite. At least immediately below the sediment/water interface, reducing conditions prevailed. Laminated shales produced by an oxygen deficiency have been described from se-

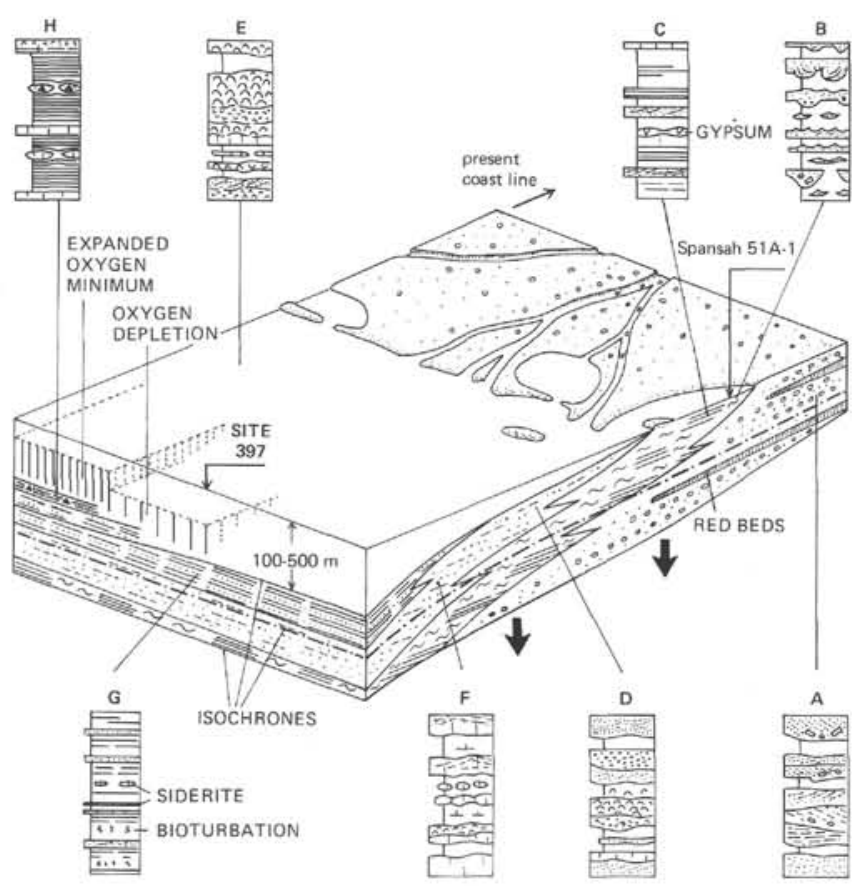

Figure 4. Block diagram showing facies model of the Hauterivian to Barremian delta on the continental margin between Site 397 and the Aaiun Basin. Note the sequence of time-transgressive (alluvial-lagoonal-intertidal-shelf or delta front-slope or prodelta facies) strata that grade laterally and vertically with respect to each other. Subsurface distribution inferred from onshore and offshore wells and outcrops. To characterize the facies of the various clastic subenvironments, typical generalized sections representing a sediment thickness of 1 to 3 meters are shown: $(A)$ alluvial delta plain sands, gravel, and red beds Aaiun (Tarfaya) Basin, Early to Middle Cretaceous); (B) interdistributory lagoonal (bay) clays, silty clays, dolomitic silts, gypsiferous marls, and limestones (? Barremian to Aptian in CONOCO well Spansah $51 \mathrm{~A}$ or in Albian coastal exposures near Tarfaya, alternating with facies $A$ ); $(C)$ intertidal muds and sands (in Barremian to Aptian coastal exposures near Tarfaya); (D) delta front sands and muds (in Barremian to Aptian coastal exposures near Tarfaya); (E) inner shelf shell beds, muds and sands (upper Albian and lower Cenomanian in coastal exposures near Tarfaya); (F) marls, bioclastic sands, and shell beds of shelf adjacent to deltaic environment (upper Albian and lower Cenomanian in coastal exposures near Tarfaya); $(G)$ prodelta silty clays and clayey silts, deposited partly under oxygen depletion (Hauterivian to Barremian at Site 397; Albian in coastal exposures, Agadir Basin); (H) dark bituminous, well-laminated, somewhat siliceous marls with intercalated organogenic limestones (Cenomanian-Turonian of coastal basin, Tarfaya). rial localities, e.g., from the upper slope off India (von Stackelberg, 1972) and from the continental slopes along western Africa and South America (DiesterHaass, in press). The combination of high sedimentation rates (e.g., by turbid layer transport) together with oxygen depletion appears to be a prerequisite for the formation of the laminated, organic-rich sediments discussed here.

\section{Diagenesis and the Origin of Siderite}

The occurrence of siderite in flat nodules and thin layers in several Lower Cretaceous samples may be important in the interpretation of the depositional environment. In ancient sediments, siderite is reported mainly from non-marine or brackish sediments (e.g., coal measures) as well as from marine sediments of relatively shallow to intermediate water depth. There is, however, still much uncertainty about its mode of formation. Berner (1971) reports that siderite has never been observed forming in modern marine sediments. Ho and Coleman (1969) describe incipient siderite nodules from a Holocene fresh-water sequence (lacustrine or poorly drained swamp environment) of the Mississippi Delta. In Lower Cretaceous sediments in northern Germany, deposited under an environment changing from non-marine to marine conditions, nodules and layers of siderite and ankerite are characteristic of marine clays (Dr. E. Kemper, personal communication).

The Deep Sea Drilling Project has revealed that diagenetically formed siderite is quite common in organic-rich marine shales in the North Atlantic. For example, Berger and von $\operatorname{Rad}(1972$, p. 817) report abundant small white siderite concretions from the Demerera Rise (DSDP Site 144). At this site, the concretions were formed in a black zeolitic carbonaceous shale of Cenomanian age, which presumably was deposited at a water depth of about $1.5 \mathrm{~km}$. Similar occurrences have been described from Sites 101 and 105 of Leg 11 and Site 398 of Leg 47B. Recently, siderite nodules were also found in nearshore Holocene muds in the Strait of Malakka, where they have probably formed by authigenic growth during early diagenesis (Dr. H. Kudrass, personal communication).

Siderite is precipitated principally during early diagenesis at a slightly negative $\mathrm{Eh}(0$ to $-200 \mathrm{mV})$ and at intermediate $p \mathrm{H}(6$ to 8$)$ values in the presence of abundant $\mathrm{Fe}^{++}$and carbon dioxide (Garrels and Christ, 1965). Such an environment can be produced under anaerobic conditions within organic-rich terrigenous or hemipelagic sediments with an abundance of $\mathrm{Fe}^{++}$, when most of the dissolved $\mathrm{S}^{2-}$ has been used up by the precipitation of pyrite (Füchtbauer and Müller, 1970 , p. 508) and bicarbonate alkalinity increases. Thus, the formation of substantial amounts of siderite implies a relatively high content of $\mathrm{Fe}^{++}$in the interstitial water and probably a nearby coastal area delivering $\mathrm{Fe}$-rich mud or groundwater. Possibly the preced- 
ing precipitation of $\mathrm{CaCO}_{3}$ as calcite cement of "precursor nodules" took place (Dr. F. Lippmann, personal communication).

From morphological evidence, it is obvious that the siderite nodules from Site 397 actually were formed during diagenesis after precipitation of pyrite, since pyrite is present in the center of some nodules (Figure 3B). Possibly, this nodule type originally consisted of calcite which later was replaced by siderite.

We also apply this interpretation to the abundantly occurring siderite layers within the well-laminated sections of Site 397. These layers apparently were deposited originally as biogenic calcite (coccoliths, etc.) or precipitated in situ as micritic calcite during early diagenesis, as in the calcite-cemented siltstones. Later, they were replaced by siderite, after the composition of the interstitial water had changed as described above.

Detailed microscope studies have shown that in Cores 397A-34 and and 397A-35 mostly resistant coccoliths (Watznaueria and Nannoconus) are present and almost invariably overgrown with carbonate, possibly siderite (F. H. Wind, personal communication). This suggests some carbonate dissolution, reprecipitation as calcite, and later transformation into siderite. Surprisingly, in Sample 397A-46-2, $120 \mathrm{~cm}$, nannofossil marls with an excellent nannofloral preservation alternate with barren siderite layers Čepek and Wind, this volume).

Thin-section analysis of a typical 6-mm-thick yellowish brown graded siderite layer (Sample 397A-46$2,70 \mathrm{~cm}$ ), which was originally described as "graded," revealed that the siderite crystallites have a uniform size ( 3 to $6 \mu \mathrm{m}$ ) from the base to the top of the layer. The graded appearance is caused only by an upward decrease of the proportion (15 to $8 \%$ ) and not of the size of quartz and feldspar grains, and by an upward increase of pigmentation by pyrite, clay minerals, and organic matter. In this case, siderite is obviously not detrital, but the secondary microsparitic cement of a compositionally graded terrigenous silt layer. We, therefore, exclude redeposition of siderite as detrital grains from a distant (lagoonal or continental) environment.

Part of the sequence observed in nearby coastal exposures, especially Albian olive-gray silty claystone with intercalated thin siltstone layers, resembles those of the Lower Cretaceous at Site 397 (Figure 4B; Plate 3 , Figures 3 through 7). However, the secondary carbonate found in these layers is calcite, Ca-dolomite, and ankerite.

Tentatively, we conclude, that the diagenesis of the Lower Cretaceous deposits of Site 397 has proceeded in three steps: (1) formation of pyrite, (2) precipitation of micritic calcite in nodules and maybe also in thin irregular layers, and (3) full or partial replacement of most calcite by siderite. An alternative explanation would be the local precipitation of siderite in thin layers during early diagenesis without a calcite precursor.

\section{Source Area of the Terrigenous Sediments}

Raising the question on the source area for the huge masses of Lower Cretaceous deltaic sediments, a wider section of the continental margin of the Early Cretaceous North Atlantic Basin has to be considered.

At Site 416 (Leg 50, water depth $4203 \mathrm{~m}$ ) in the Moroccan Basin, a 530-meter-thick upper Valanginian to Hauterivian terrigenous section was penetrated that consists of regular sequences of calcareous and quartzose fine turbiditic sandstones, siltstones, and mudstones (DSDP Initial Reports, Volume 50, in press). The extremely high Hauterivian sedimentation rate at this site $(125 \mathrm{~m} / \mathrm{m} . \mathrm{y}$.) is comparable with the rate at Site 397. This might suggest that the submarine delta system discovered off Cape Bojador, or an equivalent depocenter, extended farther north. The depositional environment of Site 416 is assumed, however, to have been much deeper (upper rise) than the prodelta of Site 397. Similar sediments as at Site 397 also occur in the Aptian/Albian record of the "Atlas Gulf" (coastal basin of Agadir-Essaouira) extending landward between Sites 397 and 416 (Behrens et al., 1978; Wiedmann et al., 1978).

Tentatively, we envisage a number of large coalescing delta systems built out into the narrow Early Cretaceous Atlantic Ocean and extending for at least 600 $\mathrm{km}$ (about 25 to $29^{\circ} \mathrm{N}$ ), in a similar way as along the contingent Early Cretaceous Nova Scotian and New Foundland continental margin (Jansa and Wade, 1975, fig. 21, 22, 33). To this Berriasian to Barremian delta system belongs the Verril Canyon Member of the Missisauga Formation consisting of medium-gray, micaceous, calcareous silty shales rich in mica, pyrite, chlorite, and charcoal. Similar to the Site 397 sediments, this formation is poor in microfauna and microflora, and it also is interpreted as being a prodelta deposit on an ancient outer shelf.

The source area of the huge amount of sediments deposited in the widespread Early Cretaceous delta system off northwest Africa cannot be clearly defined. During the Early Cretaceous, large parts of the Precambrian Requibat Massif, the Precambrian to $\mathrm{Pa}$ leozoic Mauritanides, and Anti-Atlas Mountains were elevated and being actively eroded. This area certainly lay within a zone of humid climate, since large amounts of terrestrial plant and wood debris and almost no frosted or stained "desert quartz" grains were delivered to the marginal sea. The clay mineral assemblage rich in illite $(50 \%)$, kaolinite $(15 \%)$, and chlorite (10\%) suggests a plutonic to metamorphic provenance (illite, chlorite). It also indicates weathering under a temperate and humid climate (Chamley, and d'Argoud, this volume). The heavy mineral associations (Figure 1) point to a plutonic source area. Most likely, Paleozoic sediments were also eroded. The weathered soils, including considerable quantities of sand-sized 
and silt-sized quartz, were, probably being eroded at a much higher rate than today, then transported by rivers into a wide alluvial plain with frequently shifting channel systems and from there onto the submarine part of the delta and prodelta.

\section{Hauterivian to Turonian Change and Migration of Facies}

The prodelta described above is part of a large delta system (Figure 4) built out from a wide alluvial plain.

Between the prodelta and the alluvial plain, the environments of the "interdistributory lagoons and swamps" (B in Figure 4), of the tidal flats (C) and of the inner shelf outside the delta system (E and F) can be recognized in the sedimentary record of the offshore Spansah 51A-1 well (CONOCO, 1969). They also occur in the offshore commercial wells and outcrops of the coastal basin of Aaiun-Tarfaya (Choubert et al., 1966; Querol, 1968; AUXINI, 1969; Ratschiller, 1970; Einsele and Wiedmann, 1975; von Rad et al., in press; von Rad and Einsele, in press).

During the Hauterivian, the coastline lay seaward of the present coast. The strandline, however, moved eastward onto the African continent during a major Albian-early Cenomanian transgression (Figure 5). Apparently, this rise of sea level stopped the outbuilding of the large "Wealden-type" deltas which typify the Middle Cretaceous in northwestern Europe, off northwestern Africa, and off northeastern North America. During that time, the environmental conditions at the delta slope may have started to become restricted by oxygen depletion: oceanic circulation was hindered by comparatively shallow water depth and, in comparison to the present situation, reduced by a warm, globally equable climate with low latitudinal and vertical temperature gradients (Fischer and Arthur, 1978).

In the Tarfaya-Aaiun Basin (landward of Spansah 51A-1 in Figure 5), the fluvial delta plain or "Wealden" facies (sands with gravel) of Early Cretaceous (A in Figure 4) are overlain by Aptian/Albian, finergrained, lagoonal, tidal, and shallow-marine muds, sands (including channel fill), and coquinas (B and $\mathrm{C}$ in Figure 4; Plate 3, Figures 3 through 7). During the late Albian to early Cenomanian transgression, the water depth increased and marly sediments with shell beds and sands were deposited in an inner shelf environment ( $E$ in Figure 4). The maximum water depth was reached during the late Cenomanian and Turonian. Simultaneously, the oxygen-minimum zone expanded, and laminated, carbonaceous marly shales with intercalated micritic limestones and radiolarian cherts were deposited (H in Figure 4; Einsele and Wiedmann, 1975). Schlanger and Jenkyns (1976) describe a similar midCretaceous anoxic event from other areas of the Atlantic and visualize a widespread, more or less stagnant, oxygen-minimum zone during transgressional stages. We think that this explanation should be modified by the introduction of regional upwelling (Einsele and Wiedmann, 1975) which may have started at the end of the mid-Cretaceous "stagnation period" (Ceno- manian to Turonian) along the eastern Atlantic (northwestern and southwestern Africa).

Similarly, the Hauterivian to Barremian and the Aptian to Albian sediments of the other localities shown in Figure 5 were covered by deposits of successively deeper water, if they were not eroded later on. As a consequence, the Early to Middle Cretaceous deltaic sequence of the continental margin at Cape Bojador (including the emerged part of the Aaiun Basin) generally shows a diachronous landward facies migration or "transgressive onlap" (see also Oomken, 1974). The idealized complete vertical development at each site is represented by a "fining-upward" sequence or "megacycle" beginning with coarse-grained alluvial deposits (A in Figure 4) which grade into coastal sands, shelf sediments, and finally into prodelta silty clays ( $G$ in Figure 4). Seaward of the active delta, carbonaceous marls were deposited in an outer shelf to upper slope environment ( $\mathrm{H}$ in Figure 4) during Cenomanian to Turonian time.

Simultaneously, subsidence of the continental margin slowed down (Figure 6) and input of terrigenous debris from the continent decreased. For that reason, sedimentation rates tended to decrease and the contribution of biogenic material to the total sediment became greater. Due to the slowing of subsidence, a more or less stable phase or a slow regression followed during the latest Cretaceous.

Off Cape Bojador, the present coastline lies between the Hauterivian to Barremian and the Cenomanian to Turonian strandlines (Figure 5). From the facies migration, we can also conclude that the position of the present outer shelf edge was not fixed before the Middle Cretaceous. From about the Cenomanian to Turonian, the shelf edge remained more or less stationary (i.e., between Spansah 51A-1 and DSDP 369) until today, whereas the outer part of the continental margin (i.e., present slope and rise) subsided to increasingly greater water depths (von Rad and Einsele, in press).

\section{ACKNOWLEDGMENTS}

Our shore-based investigations (grain-size analysis, binocular, and thin-section studies combined with some X-ray diffraction and scanning electron microscope work) were supplemented with a heavy reliance on the thorough descriptions by the shipboard sedimentologists (M. Arthur, B. Lopatin, M. Sarnthein, O. Weser) and paleontologists (M. Cita, P. Čepek G. Lutze, and F. Wind) (see Site Report, this volume); and on the shipboard and DSDP $\mathrm{CaCO}_{3}$ and $\mathrm{C}_{\text {org. }}$ determinations. We are grateful to Dr. F. Lippmann (Tubingen) and to Dr. H. Rosch (Hanover) for providing X-ray diffraction analyses, and to Dr. A. Butt (Tübingen) for valuable comments on the foraminiferal stratigraphy and paleoecology relative to that in the Cretaceous northwest African coastal basins. The paper was reviewed by Dr. E. Kemper (Hannover) and Prof. P. Wurster (Bonn) who suggested several improvements.

\section{REFERENCES}

AUXINI (Departamento de Investigaciones Petroliferas de AUXINI), 1969. Correlacion estratigraphica de los sondeos perforados en el Sahara español, Bol. Geol. Minero, Madrid, v. 83, p. 235-251. 


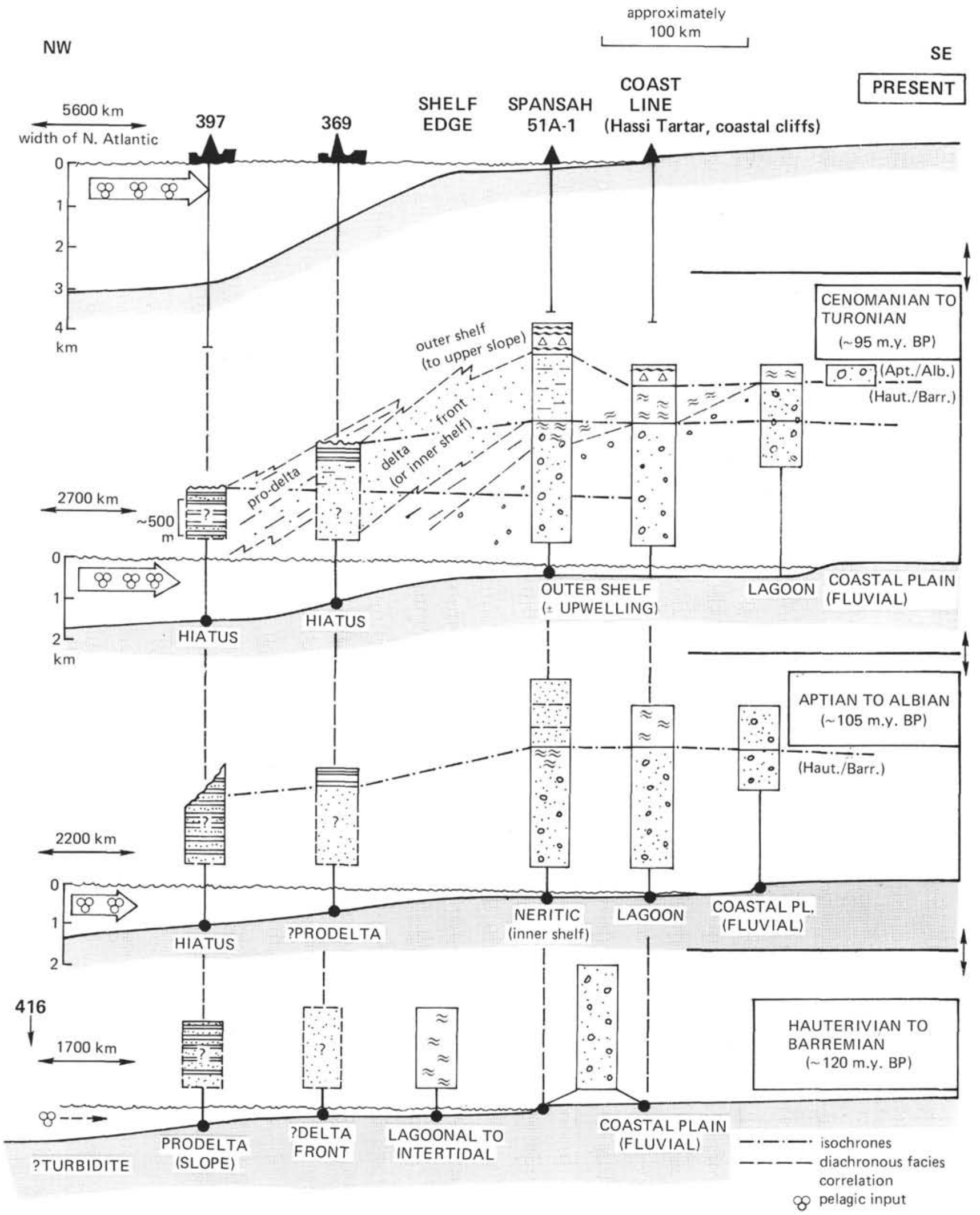

Figure 5. Tentative reconstruction of the water depth and facies domains on the Cape Bojador continental margin during the Hauterivian to Barremian, Aptian to Albian, and Cenomanian to Turonian in comparison with the present morphology. Note the landward facies migration ("onlap complex") during the Aptian to Turonian transgression (dashed lines). Paleodepths estimated from facies and subsidence history (see fig. 6; von Rad and Einsele, in press). 

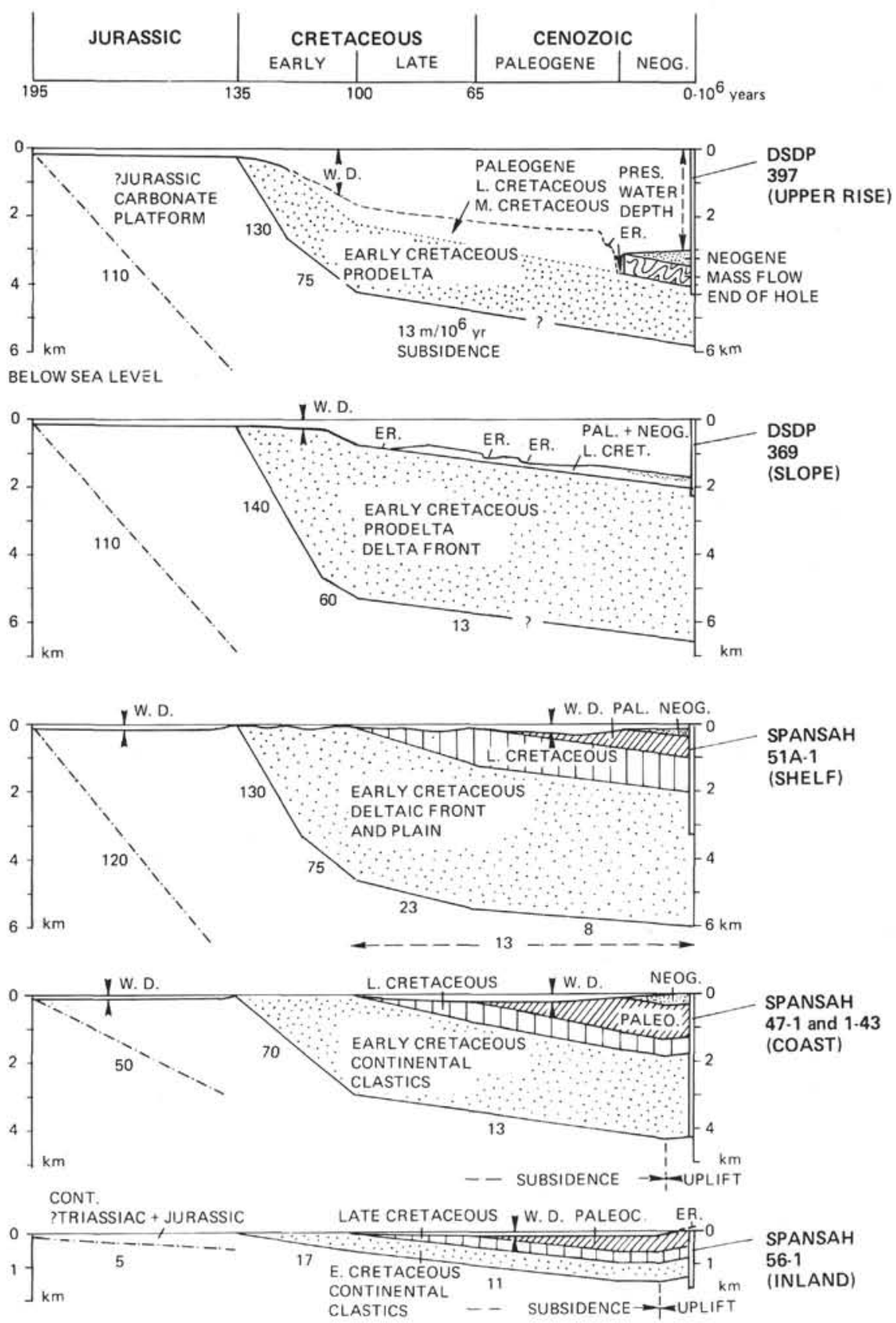

Figure 6. Late Mesozoic and Cenozoic subsidence history and changes of water depth (W.D.) at different sites across the Cape Bojador continental margin. On the right, each diagram shows the present water depth and the observed and extrapolated thickness of the different formations (below the sea floor). Rates of subsidence (numbers signify m/m.y.) and paleo-water depth are found by "backtracking" sediment thickness below sea floor from the present to the past, until a reliable facies interpretation is possible. For example, shallow water depth is found for the coastal Jurassic or Early Cretaceous. The subsidence rates inferred from the coastal basin and from the shelf site (Spansah 51A-1, CONOCO, 1969) are transferred to DSDP Site 369/Initial Reports of the Deep Sea Drilling Project, Volume 41, 1975) at the present continental slope and DSDP Site 397 at the present upper rise. PAL $=$ Paleocene, M., LT. CRET. = Middle, Late Cretaceous, ER. =Erosion, Hiatus. For further information and discussion see von Rad and Einsele (in press). 
Allen, J. R. L., 1965. Late Quaternary Niger Delta, and adjacent areas: sedimentary environments and lithofacies, $\mathrm{Am}$. Assoc. Petrol. Geol. Bull., v. 49, p. 547-600.

Berger, W. H. and von Rad, U., 1972. Cretaceous and Cenozoic sediments from the Atlantic Ocean. In Hayes, D. E., Pimm, A. C., et al., Initial Reports of the Deep Sea Drilling Project, v. 14: Washington (U. S. Government Printing Office), p. 787-954.

Berner, R. A., 1971. Principles of chemical sedimentology: New York (McGraw Hill).

Burke, K., 1972. Longshore drift, submarine canyons, and submarine fans in the development of the Niger delta. Am. Assoc. Petrol. Geol. Bull., v. 56, p. 1975-1983.

Choubert, G., Faure-Muret, A., and Hottinger, L., 1966. Aperçu géologique du Bassin Cotier de Tarfaya, Notes et Mémoirs Service géologique Maroc, v. 175, p. 7-106.

CONOCO, 1969. Spansah 51A-1, offshore Spanish Sahara. Final Report by Continental Oil Company of Spain, Spanish Gulf Oil Company, Compania Español le Petroleas S. A. Exploration Department, unpublished report and logs.

Diester-Haass, L., in press. Sediments as indicators of upwelling. Proc. Third Internat. Symposium on upwelling ecosystems. Kiel, 1975: New York, Heidelberg, Berlin (Springer Verlag).

Donaldson, A. C., Martin, R. H., and Kanes, W. H., 1970. Holocene Guadalupe delta of Texas gulf coast. In Morgan, J. P. (Ed.), Deltaic sedimentation, modern and ancient, Soc. Econ. Paleontol. Mineral., Special Publ. 15, p. 107-137.

Einsele, G. and Wiedmann, J., 1975. Faunal and sedimentological evidence for upwelling in the Upper Cretaceous coastal basin of Tarfaya, Morocco, Ninth Internat. Congress of Sedimentology, Nice, v. 1, p. 67-72

Fischer, A. G. and Arthur, M. A., 1978. Secular variations in the pelagic realm. In Cock, H. E. and Enos, P. (Eds.), Deep water carbonates and environments: Soc. Econ. Paleontol. Mineral., Spec. Publ. 25, p. 19-50.

Füchtbauer, H. and Müller, G., 1970. Sedimente und Sedimentgesteine. Sediment-Petrologie, Teil II: Stuttgart (Schweizerbart).

Garrels, R. M. and Christ, C. L., 1965. Solutions, minerals, and equilibria: New York (Harper and Row).

Gould, H. R., 1970. The Mississippi Delta complex. In Morgan, J. P. (Ed.), Deltaic sedimentation, modern and ancient: Soc. Econ. Paleontol. Mineral., Spec. Publ. 15, p. 3-30.

Ho, C. and Coleman, J. M., 1969. Consolidation and cementation of recent sediments in the Atchafalaya Basin, Geol. Soc. Am. Bull., v. 80, p. 183-192.
Jansa, L. F. and Wade, J. A., 1975. Geology of the continental margin off Nova Scotia and Newfoundland. Offshore Geology of Eastern Canada, Geol. Survey Canada, Paper 74-30, v. 2 (Regional Geology).

Moore, D.G., 1968. Reflection profiling studies of the California continental borderland: structure and Quaternary trubidite basisn, Geol. Soc. Am. Spec. Papers, v. 107, 142 pp.

Oomkens, E., 1974. Lithofacies relations in the Late Quaternary Niger Delta complex, Sedimentology, v. 21, p. 195222.

Querol, R., 1966. Regional geology of the Spanish Sahara. In Reyre, D. (Ed.), Sedimentary basins of the African coast: Assoc. of African Geol. Surveys, Paris, p. 27-39.

Ratschiller, L. K., 1970. Lithostratigraphy of the northern Spanish Sahara. Memorie del Museo Tridentino di Scienze Naturali, Trento, v. 18, p. 9-84.

Reineck, H. E. and Singh, I. B. 1973. Depositional sedimentary environments (with reference to terrigenous clastics): New York, Heidelberg, Berlin (Springer),

Schlanger, S. O. and Jenkyns, H. C., 1976. Cretaceous oceanic anoxic sediments: causes and consequences, Geologie en Mijnbouw, v. 55, p. 179-184.

Shipboard Scientific Party of DSDP Leg 41, 1975. The eastern North Atlantic, Geotimes, v. 20, p. 18-21

Shipboard Scientific Party of DSDP Leg 50, 1977. In the Atlantic: documenting early rifting, Geotimes, v. 22 (April), p. 24-27.

van Hinte, J. E., 1976. A Cretaceous time scale, Am. Assoc. Petrol. Geol. Bull., v. 60, p. 498-516.

von Rad, U., Čepek, P., von Stackelberg, U., Wissmann, G., and Zobel. B., 1978. Cretaceous and Tertiary sediments from the Northwest African slope (dredges and cores supplementing DSDP results), Mar. Geol., v. 28.

von Rad, U. and Einsele, G., in press. Mesozoic-Cenozoic subsidence history and paleobathymetry of the Northwest African continental margin (Aaiun Basin to DSDP Site 397), Philosophical Transactions of the Royal Society, London.

von Stackelberg, U., 1972. Faziesverteilung in Sedimenten des indisch-pakistanischen Kontinentalrandes (Arabisches Meer). "Meteor"-Forschungsergebnisse, Reihe C, no. 9, p. $1-73$.

Wiedmann, J., Butt, A., and Einsele, G., 1978. Vergleich von marokkanischen Kreide-Kustenaufschlussen und Tiefseebohrungen (DSDP): Stratigraphie, Palaoenvironment und Subsidenz an einem passiven Kontinentalrand, Geol. Rundschau, v. 67, p. 454-508. 
PLATE 1

Thin-Section Photomicrographs and Enlarged Shipboard Core Photos From the Hauterivian-Barremian Unit of DSDP Hole 397A

Figure 1

Figure 2

Figure 3

Figure 4

Figure 5

Figure 6

Figure 7

Figure 8
Sample 397A-39-2, CC. Well-sorted quartz siltstone to very fine sandstone layer, cemented by microsparitic calcite. Note color gradation by upward increase of dark-colored material (mica, clay minerals, plant debris).

Sample 397A-47-4,CC. Lenticular (flaser) bedding with pyrite and organic-rich dark and quartz-silt-rich light-colored laminae. Note ?cutand-fill structure near top.

Sample 397A-46-4, 91-93 cm. Silty claystone with bioturbation at the transition from dark- to light-colored layer.

Sample 397A-48-2, 56-59 cm. Crossed nicols. Alternating layers and micro-lenses of pure clay (light-colored), silty clay (dark), and clay, rich in organic matter (black).

Sample 397A-46-4, 91-93 cm. Small erosional unconformity between pure claystone with dark burrow (base) and silty claystone rich in plant debris (top).

Sample 397A-43-1, 95-98 cm. Claystone with angular quartz silt and spheroidal aggregates of biogenic origin (probably megaspores).

Sample 397A-46-3, 55-100 cm. Medium to lightgray, well-laminated nannofossil marlstone with tiny yellow specks of Nannoconus sp. Dark layers are carbonate-poor claystone. Note crosslamination at $97-89 \mathrm{~cm}$.

Sample 397 A-43-1, 65-80 cm. Partly massive $(70-75 \mathrm{~cm})$, partly laminated silty claystone with 1-cm-thick light-colored siderite layer (69$70 \mathrm{~cm})$ and thin ?siderite laminae $(75-76 \mathrm{~cm})$. 
PLATE 1
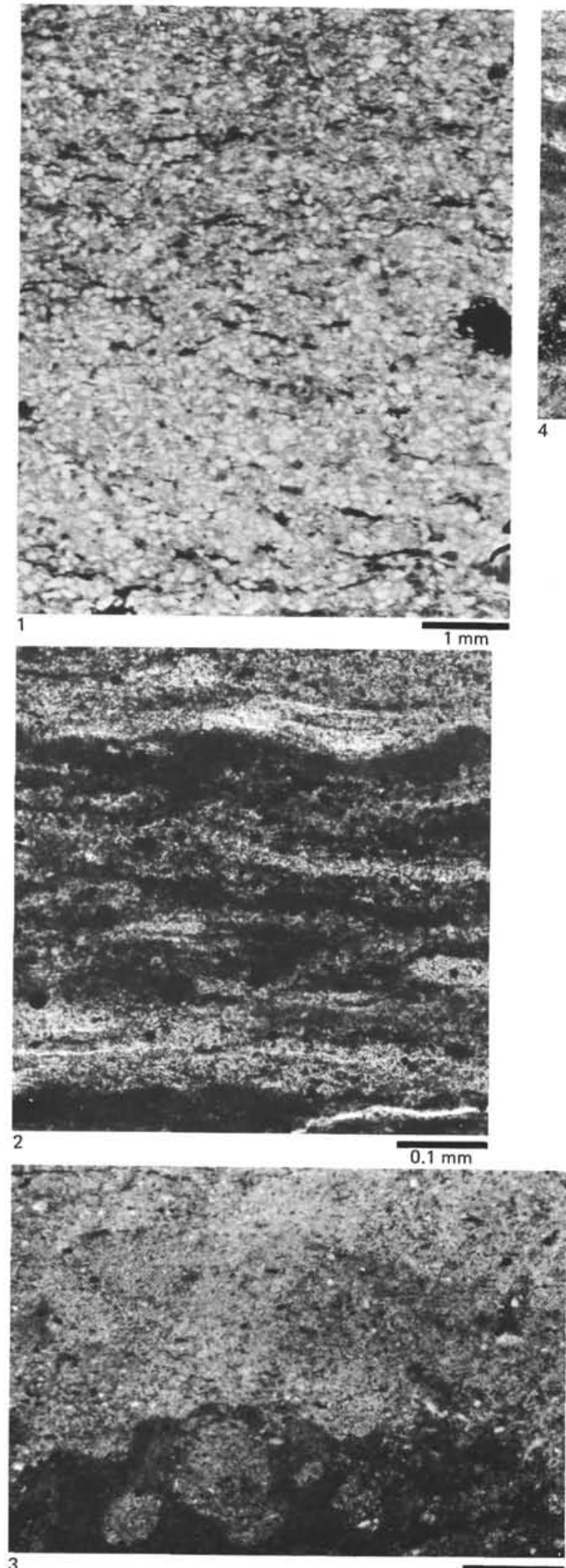

$0.5 \mathrm{~mm}$
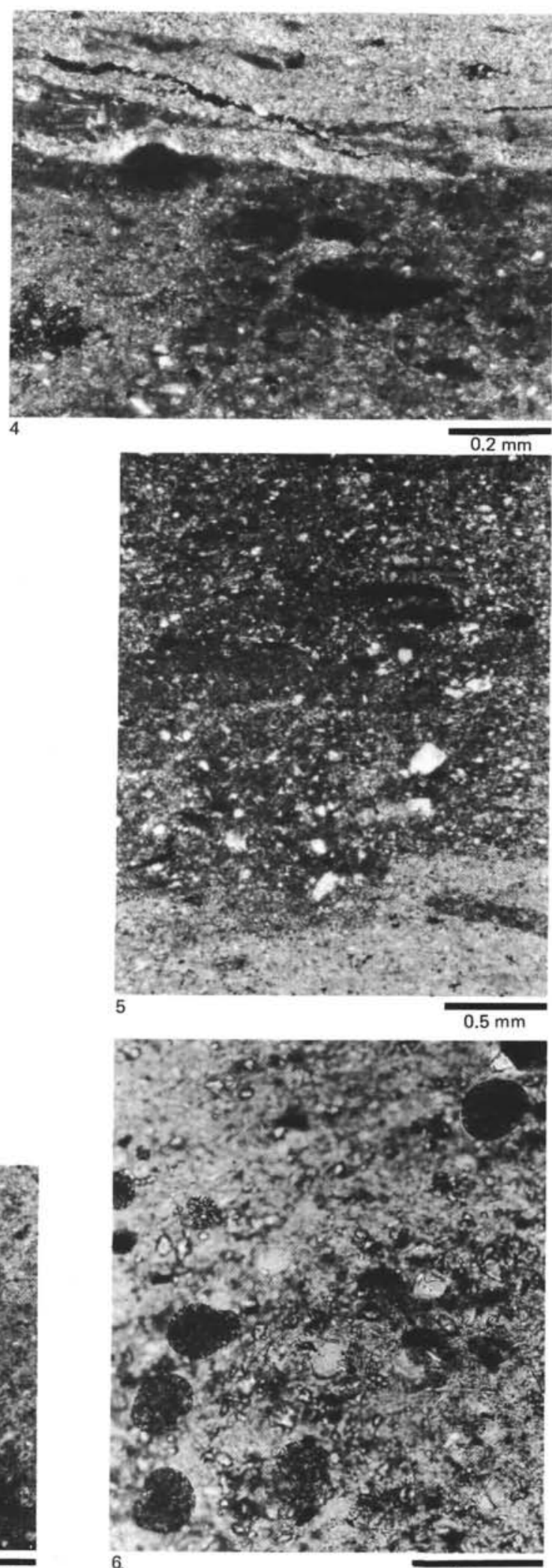

$0.1 \mathrm{~mm}$
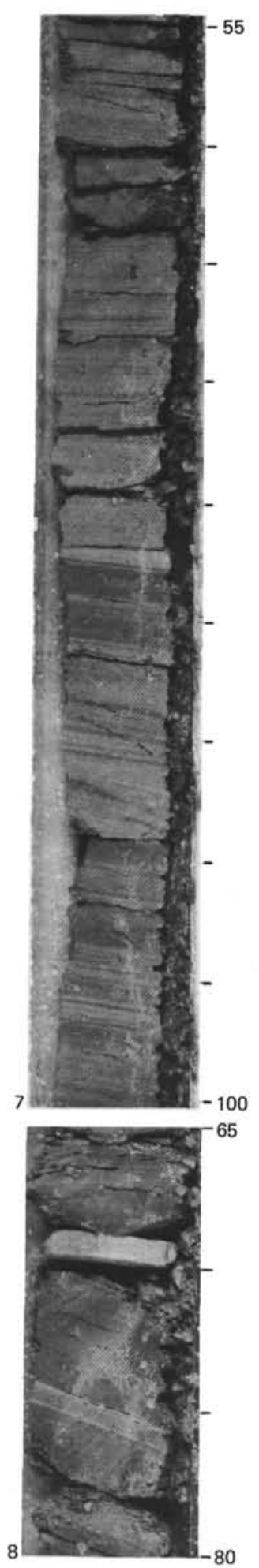


\section{PLATE 2}

Thin-Section and SEM Photos of the Hauterivian Unit 5 of DSDP Hole 397A

Figure 1 Sample 397A-48-2, 86-88 cm. Total thin-section photo. Parallel to lenticular lamination and bioturbation (for explanation see Figure $2 \mathrm{~A}$ in text).

Figure 2 Sample 397A-51-3, 90-93 cm. Total thin-section photo. Slumped ("folded," "faulted," and pulled-apart) siderite laminae in silty claystone (see also Figure $3 \mathrm{~A}$ in text).

Figure 3

Sample 397A-44-1, 129-131 cm. Total thin-section photo. Indistinct graded siltstone to very fine sandstone layer overlain by clean claystone and (top) silty claystone. Upper two-thirds of siltstone layer are diagenetically sideritized, i.e., very dark (see also Figure $2 \mathrm{C}$ in text).

Figure 4 Sample 397A-50-3, 18-21 cm. Total thin-section photo. Siderite nodule, concentrically surrounded by laminated silty claystone with very thin siderite layers (dashed lines). Apparently overturned slump fold (see also Figure $3 \mathrm{~B}$ in text).

Figure 5 Sample 397A-50-3, 18-21 cm. SEM photo, $7500 \times$. Small euhedral siderite rhombs in cavity of micritic siderite nodule.

Figure 6 Sample 397A-39-1, 95-97 cm. SEM photo. Small euhedral siderite rhombs growing between lamellae of ?mica (early digenetic origin). 
PLATE 2
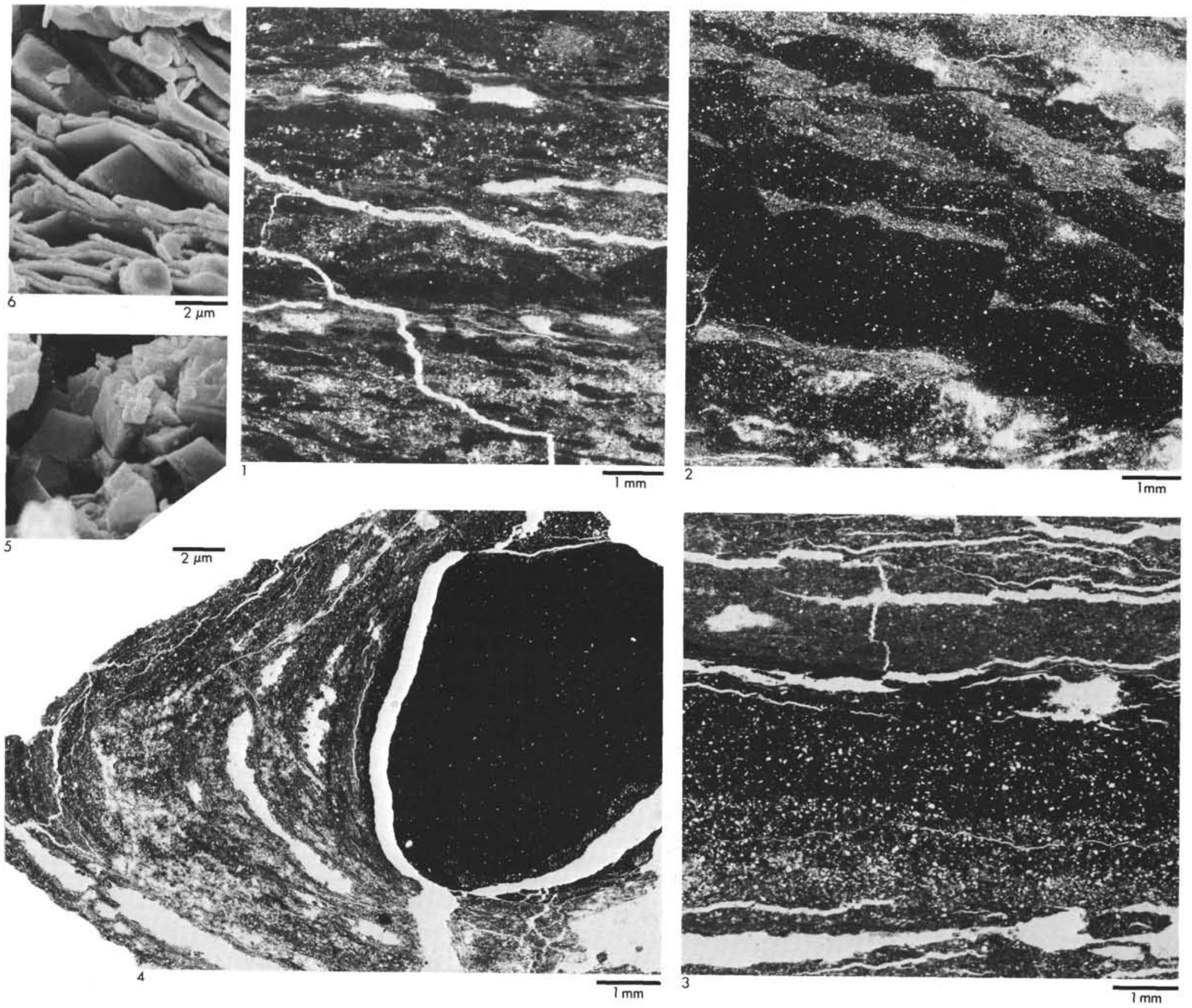
PLATE 3

Core Photos From Hole 397A (Figures 1 and 2) and ThinSection Photomicrographs of Albian Clastic Shallow-Water Sediments From Exposures of the Coastal Aaiun-Tarfaya Basin (Figures 3 through 7)

Figure 1 Sample 397A-51-6, 50-75 cm. Comparatively massive silty claystone with crinkled, streaky siderite layers (? sheared parallel to the bedding plane, e.g., $53 \mathrm{~cm}$ ) and contorted slump fold of a thick siderite layer $(70 \mathrm{~cm})$. Note embryonic shear planes and thinned-out lower limb of fold (Dr. M. Sarnthein, personal communication).

Figure 2 Sample 397A-50-1, 30-50 cm. Parallel laminated silty clay with siderite nodule elongated parallel to bedding $(35 \mathrm{~cm})$ and intraformational slumping (recumbent fold at $45 \mathrm{~cm}$ ).

Figure 3 Siltstone to very fine quartz sandstone, carbonate cemented, with fragments of bones and mollusks. Middle Albian (Tassag-delta, southern Morocco).

Figure 4 Laminated light olive-gray claystone. Note the quartz grains dispersed in the clayey matrix. Upper Albian (mouth of Chebeika River, southern Morocco).

Figure 5 Laminated light olive-gray claystone with intercalations of laminated carbonate-cemented siltstone (same age and locality as Figure 4).

Figure 6 Coquina with clayey silty matrix (same age and locality as Figure 3).

Figure 7 Bone fragment in fine quartz sandstone, cemented by Ca-dolomite. Middle Albian (coast south of Tan-Tan, southern Morocco). 
PLATE 3
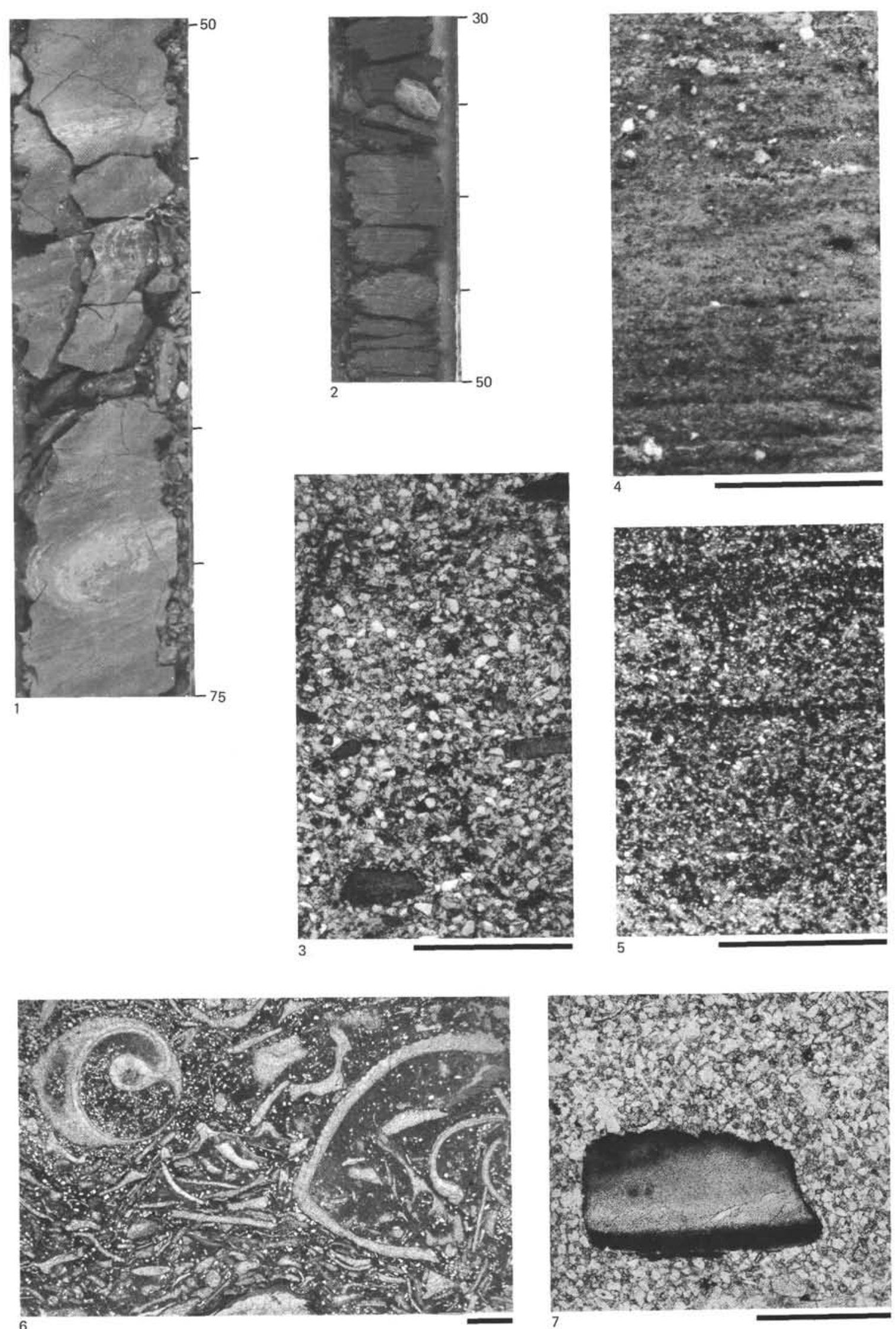